\title{
Pengaruh Kondisi Simpan Terhadap Viabilitas dan Vigor Benih Tomat (Lycopersicum esculentum, Mill)
}

\author{
Emerensiana Kolo ${ }^{a}$ dan Anna Tefa ${ }^{b}$ \\ ${ }^{a}$ Fakultas Pertanian, Universitas Timor, Kefamenanu, TTU - NTT, Indonesia. \\ ${ }^{b}$ Fakultas Pertanian, Universitas Timor, Kefamenanu, TTU - NTT, Indonesia.
}

\section{Article Info}

\section{Article history:}

Received 1 Februari 2016

Received in revised form 27 Februari 2016

Accepted 1 Maret 2016

\section{Keywords:}

Kondisi Simpan

Viabilitas

Vigor

Lycopersicum esculentum, Mill

\section{Abstrak}

Penelitian bertujuan untuk mengetahui pengaruh kondisi simpan yang tepat terhadap viabilitas dan vigor benih tomat selama penyimpanan serta mengetahui lama periode simpan terhadap viabilitas dan vigor benih tomat. Penelitian mengunakan Rancangan Acak Lengkap (RAL), pola faktorial, dengan dua perlakuan yang terdiri dari kondisi simpan dan periode simpan benih.Faktor pertama kondisi simpan, yang terdiri dari dua aras yakni penyimpanan benih pada suhu kamar (KM ), dan penyimpanan benih pada suhu kulkas (KL), faktor kedua periode simpan, terdiri dari 7 aras yakni 0 minggu (S1), 2 minggu (S2), 4 minggu (S3), 6 minggu (S4), 8 minggu (S5), 10 minggu (S6), dan 12 minggu (S7). Hasil penelitian menunjukkan kondisi simpan dan lamanya periode simpan memberikan pengaruh interaksi terhadap parameter kadar air dan kecepatan tumbuh. Suhu kulkas selama periode simpan S12 memberikan pengaruh yang nyata terhadap parameter kecepatan tumbuh, potensi tumbuh maksimum, daya berkecambah, dan indeks vigor, dan memberikan pengaruh yang sangat nyata pada parameter kadar air, keserempakan tumbuh, dan berat kering kecambah normal. Kondisi simpan pada benih yang disimpan pada suhu kulkas selama 12 minggu memberikan nilai kecamabah normal tertinggi untuk setiap parameter pengamatan. @2016 dipublikasikan oleh Savana Cendana.

\section{Pendahuluan}

Tomat (Lycopersicum esculentum, Mill.) merupakan salah satu komoditas hortikultura yang bernilai ekonomi tinggi dan masih memerlukan penanganan serius, terutama dalam hal peningkatan hasil dan kualitas buahnya. Warna merah yang dimiliki buah tomat, terkandung manfaat dan khasiat yang sangat besar. Buah tomat sangat baik untuk mencegah dan mengobati berbagai macam penyakit, seperti sariawan karena mengandung vitamin $\mathrm{C}$, mencegah pembentukan batu dalam saluran kencing, dan bahkan tomat dapa menyembuhkan sakit lever, encok dan lain sebagainya (Rukmana,1994). Selain sebagai buah segar yang langsung dapat dikonsumsi, buah tomat juga dapa digunakan sebagai bahan penyedap berbagai macam masakan seperti sup, gadogado, sambal, dan juga dapat dijadikan bahan industri untuk dikonsumsi dalam bentuk olahan, misalnya untuk minuman sari buah tomat, dan es jus tomat Berbagai macam kegunaan tersebut dapat memberikan keuntungan, baik bagi konsumen, produsen, maupun masyarakat pada umumnya (Cahyono,1998).

Menurut Direktorat Jenderal Hortikultura (2011), produksi tomat nasional mencapai 954.046 ton, sedangkan potensi produksi tomat dapat mencapai 75-80 ton/ha, sementara produksi tomat di Kabupaten Timor Tengah Utara (TTU), dar tahun 2013-2014 sebesar 184 ton, dengan luas tanam 55 ha, sedangkan potensi produksi tomat dapat mencapai 35-50 ton/ha

Selama penyimpanan, benih mengalami kemunduran viabilitas dan vigor, terutama berhubungan dengan kadar air benih. Tingkat kadar air aman untuk penyimpanan benih tergantung pada jenis benih, metode penyimpanan, dan lama penyimpanan (Harrington, 1973). Penyimpanan yang lama memerlukan kadar air yang rendah untuk mempertahankan viabilitasnya. Daya berkecambah benih merupakan salah satu parameter yang bersifat langsung menggambarkan viabilitas benih (Hendrawati, 1993). Daya berkecambah benih ini dapat digunakan sebagai parameter untuk menetapkan umur simpan suatu benih dan untuk uji tingkat kadar air yang terbaik untuk penyimpanan. Penentuan umur simpan benih umumnya dilakukan secara empiris dengan percobaan menyimpan benih pada berbagai kondisi dan lama penyimpanan. Kemudian umur simpannya ditentukan berdasarkan mutu benih pada perlakuan umur simpan tertentu saa benih memenuhi persyaratan mutu standar atau yang masih dapat diterima. Dalam uji umur simpan parameter penting ialah kadar air awal benih dan jenis kemasan (Maryanto, 1994), kelembapan dan suhu ruang penyimpanan (Hartini, 1997).

Keberhasilan produksi tanaman di lapangan salah satunya ditentukan oleh penggunaan benih yang baik dan bermutu. Ekstraksi benih merupakan suatu tindakan untuk memisahkan biji calon benih dari buah sehingga diperoleh benih dalam keadaan yang bersih (Stubsgoard dan Moestrup, 1994). Benih yang dihasilkan dari penerapan teknik ekstraksi termasuk benih tomat tidak semua langsung dipakai atau ditanam, sering sebagian atau seluruh benih mengalami proses penyimpanan baik jangka pendek maupun jangka panjang (Raka, et al. 2012). Daya berkecambah benih selama penyimpanan sangat dipengaruhi oleh kadar air benih, suhu, dan kelembaban nisbi ruangan, dan viabilitas awal benih sebelum disimpan (Justice dan Bass, 1994). Kadar air benih sangat dominan peranannya terhadap daya berkecambah benih selama penyimpanan. Delouche (1971), menyatakan bahwa tingkat vigor awal benih tidak dapat dipertahankan, dan benih yang disimpan selalu mengalami proses kemunduran mutunya secara kronologis selama penyimpanan. Sifat kemunduran ini tidak dapat dicegah dan tidak dapat balik atau diperbaiki secara sempurna. Laju kemunduran mutu benih hanya dapat diperkecil dengan melakukan pengolahan dan penyimpanan secara baik. Berapa lama benih dapat disimpan sangat bergantung pada kondisi benih terutama kadar air benih dan lingkungan tempat benih disimpan.

Produksi tanaman yang tinggi dengan kualitas yang baik dibutuhkan juga benih dengan kualitas tinggi pula. Keberhasilan usaha tani salah satunya ditentukan oleh kualitas benih (Kusandriani dan Muharam, 2005). Berbagai faktor budidaya harus diperhatikan, diantaranya adalah teknik penyimpanan benih yang baik bagi tanaman. Salah satu faktor yang menentukan keberhasilan usaha tani adalah ketersediaan benih bermutu tinggi. Benih bermutu tinggi dapa diperoleh dari benih sumber dengan mutu genetik tinggi, perlu diperhatikan juga cara budidaya tanaman yang optimal, pemeliharaan, panen, pasca panen, dan penyimpanan benih yang baik (Kusandriani dan Muharam, 2005). Benih yang bermutu tinggi yaitu benih yang memiliki viabilitas dan vigor yang tinggi. Faktor-faktor yang mempengaruhi viabilitas dari benih adalah viabilitas awa benih, tingkat kemasakan benih saat panen, lingkungan sebelum panen, dan lingkungan selama periode penyimpanan benih.

\section{Metode}

Penelitian dilaksanakan bulan Oktober 2015 sampai Januari 2016 di Laboratorium Fakultas Pertanian Universitas Timor, Kelurahan Sasi, Kecamatan Kota Kefamenanu, Kabupaten TTU. Rancangan yang digunakan adalah Rancangan Acak Lengkap (RAL) dengan dua perlakuan yang terdiri dari kondisi simpan dan periode simpan benih. Faktor pertama kondisi simpan, yang terdiri dari dua aras yakni penyimpanan benih pada suhu kamar atau suhu tinggi (KM 1), dan penyimpanan benih pada suhu rendah atau suhu kulkas (KL 2), faktor kedua periode simpan (S) yakni 0 minggu (S1), 2 minggu (S2), 4 minggu (S3), 6 minggu (S4), 8 minggu (S5), 10 minggu (S6), dan 12 minggu (S7). Data hasi pengamatan kemudian dianalisis dengan menggunakan sidik ragam (Anova) Rancangan Acak Lengkap (RAL). Rata-rata perlakuan selanjutnya diuji lanjut dengan menggunakan Duncan Multiple Range Test (DMRT) dengan tingkat signifikasi 5\% sesuai petunjuk Gomez dan Gomez, (1995). Analisis data menggunakan program SAS 9.1

\section{Hasil dan Pembahasan}

\subsection{Kadar Air}

Benih pada saat dipanen memiliki kandungan air benih sekitar $16 \%$ sampai $20 \%$. Agar dapat mempertahankan viabilitas maksimumnya maka kandungan ai harus diturunkan terlebih dahulu sebelum disimpan. Dalam batas tertentu makin rendah kadar air benih makin lama daya hidup benih tersebut. Kadar air benih selama penyimpanan merupakan faktor yang mempengaruhi viabilitas dan vigor benih (Sutopo, 1998).

Hasil sidik ragam (Anova) menunjukkan terjadi pengaruh interaksi antara perlakuan suhu dan periode simpan. Berdasarkan Tabel 1. menunjukkan bahwa perlakuan penyimpanan pada S12 dengan perlakuan suhu kamar memberikan pengaruh yang berbeda nyata dengan perlakuan lainnya tetapi tidak berbeda nyata dengan perlakuan simpan S10. Benih yang disimpan pada suhu kulkas, kadar airnya semakin lama semakin menurun tetapi dapat meningkatkan jumlah kecambah normal selama persemaian. Sedangkan pada suhu kamar semakin lama disimpan semakin tinggi kadar air benih namun dapat menurunkan jumlah kecambah normal. Pada suhu kulkas respirasi berjalan lambat. Dengan demikian viabilitas dan vigor benih dapat dipertahankan lebih lama sedangkan pada suhu kamar respirasi berjalan lebih aktif sehingga dapat menurunkan daya tumbuh serta vigor benih. Jadi kadar air terendah terdapat pada suhu kulkas minggu ke12, dan kadar air tertinggi terdapat pada suhu kamar minggu ke-12.

Selama penyimpanan, benih mengalami kemunduran viabilitas dan vigor, terutama berhubungan dengan kadar air benih. Tingkat kadar air aman untuk penyimpanan benih tergantung pada jenis benih, metode penyimpanan dan lama penyimpanan (Harrington, 1973). Kandungan air benih tomat dibawah 4\% mempercepat kemunduran benih yang disebabkan oleh autoksidasi lipid didalam benih sedangkan benih diatas $14 \%$ akan terdapat cendawan gudang yang merusak kapasitas perkecambahan benih

Penelitian, Julianti, et al. (2011), Semakin tinggi kadar air kerusakan benih makin tinggi yang ditandai dengan viabilitas benih yang semakin cepat menurun. Pengaruh kadar air benih cabe merah selama penyimpanan berkorelasi dengan suhu dan kelembapan. Makin tinggi kelembapan dengan sendirinya juga kadar air, maka viabilitas benih makin menurun. Pada kadar air sangat rendah (3.0 dan $5.2 \%$ ) yang seimbang pada kelembapan $11 \%$ dan $42 \%$, viabilitas benih tidak berubah yaitu tetap $100 \%$ sampai penyimpanan 6 bulan. Pada kadar air 6.5 $\%$, yang seimbang dengan kelembapan $43 \%$, terjadi periode viabilitas konstan 
$100 \%$ sampai 4 bulan, dan pada kadar air $7.6 \%$, yang seimbang dengan kelembapan $58 \%$ periode viabilitas konstan 3 bulan. Sedangkan pada kadar air $14.3 \%$, yang seimbang dengan kelembapan $85 \%$, atau lebih tinggi tidak mempunyai periode viabilitas konstan. Jadi makin rendah kadar air benih makin panjang periode viabilitas konstan. Hal ini berhubungan dengan aktivitas enzimenzim yang berperan dalam proses pertumbuhan kecambah, sesuai dengan pendapat Labuza (1978) yang menyatakan bahwa enzim tidak aktif didaerah fraksi air pertama atau air terikat primer (ATP), dan aktivitas enzim mulai terjadi di awal fraksi air ke dua atau air terikat sekunder (ATS), yang makin meningkat aktivitasnya makin tinggi tingkat kadar airnya. Pendapat tentang perbedaan pengaruh fraksi air ini diakui oleh banyak peneliti (Bourne, 1987).
Penelitian Palupi, et al (2011), penyimpanan di ruang ber AC ini dengan kelembapan antara $60-80 \%$ dan suhu antara $18-20{ }^{\circ} \mathrm{C}$ ), dapat mempertahankan viabilitas dan vigor benih cabai rawit, lebih baik dibanding di ruang tanpa $\mathrm{AC}$ dengan kelembapan antara 50-90\% dan suhu $28-32{ }^{\circ} \mathrm{C}$ ).

Hasil penelitian Kartono (2004), menunjukkan bahwa walaupun kadar air awal penyimpanan rendah, penyimpanan pada ruang terbuka menyebabkan kerusakan benih yang tinggi, menurunkan daya kecambah, dan daya simpan benih kedelai yang singkat. Penyimpanan benih di daerah tropis yang memiliki suhu dan kelembaban tinggi sepanjang tahun dapat memperpendek masa simpan benih, karena kondisi ini akan memacu laju respirasi dan laju deteriorasi benih, sehingga persentase viabilitas benih akan cepat menurun.

Tabel 1. Kadar Air (\%)

\begin{tabular}{ccccccccc}
\hline \multirow{2}{*}{ Perlakuan } & \multicolumn{7}{c}{ Simpan } & \multirow{2}{*}{ Rerata } \\
\cline { 2 - 8 } & S0 & S2 & S4 & S6 & S8 & S10 & S12 & \\
\hline KM & $5.50 \mathrm{e}$ & $6.96 \mathrm{~d}$ & $7.08 \mathrm{~cd}$ & $7.57 \mathrm{bcd}$ & $7.88 \mathrm{abc}$ & $8.08 \mathrm{ab}$ & $8.56 \mathrm{a}$ & $7,38 \mathrm{a}$ \\
KL & $5.50 \mathrm{e}$ & $5.33 \mathrm{e}$ & $4.98 \mathrm{ef}$ & $4.87 \mathrm{eg}$ & $4.67 \mathrm{efg}$ & $4.21 \mathrm{fg}$ & $4.10 \mathrm{~g}$ & $4,81 \mathrm{~b}$ \\
\hline Rerata & $5,50 \mathrm{e}$ & $6,15 \mathrm{~cd}$ & $6,03 \mathrm{de}$ & $6,22 \mathrm{ab}$ & $6,28 \mathrm{~b}$ & $6,15 \mathrm{abc}$ & $6,34 \mathrm{a}$ & + \\
\hline
\end{tabular}

Keterangan : Angka pada baris dan kolom yang diikuti dengan huruf yang sama tidak berbeda nyata menurut uji DMRT @ 5\%, KM : kamar, $\mathrm{KL}$ : kulkas, S : simpan, (+) = Terjadi interaksi antar faktor.

\subsection{Kecepatan Tumbuh}

Kecepatan tumbuh merupakan salah satu indikator vigor. Tingginya nilai $\mathrm{K}_{\mathrm{C}} \mathrm{T}$ menunjukkan semakin tinggi pula vigor benih tersebut (Sutopo, 2004). Salah satu tolok ukur vigor kekuatan tumbuh benih adalah kecepatan tumbuh $\left(\mathrm{K}_{\mathrm{c}} \mathrm{t}\right)$. Kecepatan tumbuh dapat dilihat dari laju proses perkecambahan dalam waktu yang lebih singkat.

Hasil sidik ragam (Anova) menunjukkan terjadi pengaruh interaksi antara perlakuan suhu dan periode simpan. Data Tabel 2. menunjukkan bahwa pada perlakuan suhu kamar dengan periode simpan, semakin lama benih disimpan semakin rendah nilai $\mathrm{K}_{\mathrm{C}} \mathrm{t}$, sedangkan pada perlakuan suhu kulkas semakin lama benih disimpan akan semakin meningkatkan nilai $\mathrm{K}_{\mathrm{c}} \mathrm{t}$ setiap persemaian Peningkatan nilai rata-rata kecepatan tumbuh pada suhu kulkas menunjukkan bahwa benih mengalami peningkatan daya kecambah selama proses penyimpanan dengan diikuti penurunan persentase kadar air. Hal ini disebabkan karena pada suhu kulkas respirasi dapat berjalan lambat sehingga viabilitas dan vigor benih dapat dipertahankan lebih lama.
Perlakuan suhu kamar dengan periode simpan S12 memberikan pengaruh yang berbeda nyata dari perlakuan lainnya tetapi tidak berbeda nyata dengan periode simpan S10. Kecepatan tumbuh tertinggi mampu dipertahankan hingga mencapai $9.85 \% \mathrm{KN} /$ etmal pada periode simpan 12 minggu pada perlakuan suhu kulkas dan terendah pada periode simpan S0 minggu. Akan tetapi untuk setiap kondisi simpan yakni suhu kamar dan suhu kulkas setiap 2 minggu persemaian jumlah kecambah normal bersifat fluktuatif.

Penyimpanan benih menghasilkan kecepatan berkecambah dengan nilai rata-rata semakin meningkat dengan semakin lama periode penyimpanan pada suhu kulkas. Justice dan Bass, (2002), mengatakan bahwa, pemanenan yang dilakukan pada masa benih mencapai masak fisiologis memiliki nilai kecepatan tumbuh dan keserempakan tumbuh yang lebih tinggi dari benih yang dipanen setelah lewat masak. Sadjad (1980) juga menambahkan bahwa benih yang dipanen saat mencapai masak fisologis memiliki nilai kecepatan tumbuh lebih tinggi dari benih-benih yang telah lewat masa masak fisiologisnya.

Tabel 2. Kecepatan Tumbuh (\% per etmal)

\begin{tabular}{ccccccccc}
\hline \multirow{2}{*}{ Perlakuan } & \multicolumn{7}{c}{ Simpan } & \multirow{2}{*}{ Rerata } \\
\cline { 2 - 8 } & S0 & S2 & S4 & S6 & S8 & S10 & S12 & \\
\hline KM & $5.45 \mathrm{~d}$ & $7.63 \mathrm{abcd}$ & $8.67 \mathrm{abc}$ & $7.64 \mathrm{abcd}$ & $7.63 \mathrm{abcd}$ & $7.42 \mathrm{bcd}$ & $6.67 \mathrm{~cd}$ & $7,30 \mathrm{~b}$ \\
KL & $5.45 \mathrm{~d}$ & $8.01 \mathrm{abc}$ & $8.72 \mathrm{abc}$ & $8.52 \mathrm{abc}$ & $9.20 \mathrm{ab}$ & $8.20 \mathrm{abc}$ & $9.85 \mathrm{a}$ & $8,28 \mathrm{a}$ \\
\hline Rerata & $5,45 \mathrm{e}$ & $7,82 \mathrm{~d}$ & $8,70 \mathrm{a}$ & $8,08 \mathrm{~cd}$ & $8,42 \mathrm{ab}$ & $7,81 \mathrm{~d}$ & $8,26 \mathrm{bc}$ & + \\
\hline \multicolumn{2}{l}{ Keterangan : Angka pada baris dan kolom yang diikuti dengan huruf yang sama tidak berbeda nyata menurut uji DMRT @ $5 \%$, KM : kamar, }
\end{tabular}

$\mathrm{KL}$ : kulkas, $\mathrm{S}$ : simpan, $(-)=$ Tidak terjadi interaksi antar faktor.

\subsection{Potensi Tumbuh Maksimum}

Potensi tumbuh maksimum merupakan salah satu parameter viabilitas benih (Sutopo, 2004). Besarnya nilai PTM menunjukkan kondisi viabilitas benih yang tinggi (Justice dan Bass, 2002).

Benih yang disemaikan semakin hari akan semakin bertumbuh. Sejauh mana benih bertumbuh akan memiliki batas tumbuh benih. Kemampuan tanaman untuk dapat tumbuh dan berkembang menjadi besar tergantung pada kondisi benih itu sendiri. Mugnisjah dan Setiawan (2004), menyatakan bahwa kemampuan tanaman untuk dapat mempertahankan mutu benih berbeda-beda jika dipandang dari individu benih yang membentuk kelompok (lot). Potensi tumbuh maksimum berarti benih yang dapat tumbuh baik yang normal maupun abnormal pada batas tertentu.

Berdasarkan Tabel 3. perlakuan suhu kulkas dengan periode S12 memberikan pengaruh yang nyata dan berbeda dengan perlakuan lainnya tetapi tidak berbeda nyata dengan perlakuan S4. Potensi tumbuh maksimum tertinggi terdapat pada benih yang disimpan pada suhu kulkas selama periode simpan 12 minggu, sedangkan PTM terendah terdapat pada benih yang disimpan pada suhu kamar selama periode simpan 10 minggu. Akan tetapi untuk masing-masing kondisi simpan yakni suhu kulkas dan suhu kamar potensi tumbuh benih selama penyimpanan bersifat fluktuatif.

Benih yang disimpan dengan baik mempunyai daya tumbuh yang tinggi saat ditanam kembali. Pada parameter potensi tumbuh maksimum terjadi peningkatan jumlah kecambah normal maupun abnormal pada perlakuan suhu kulkas selama periode simpan ke 12 minggu. Hal ini disebabkan benih yang disimpan pada suhu kulkas dapat mempertahankan mutu fisiologis benih selama periode penyimpanan dan dapat menghambat keceptan kemunduran benih (deteriorasi). Menurut Viera et. al, (2001) benih yang disimpan pada lingkungan yang menguntungkan (suhu kulkas), maka kualitas benihnya masih tinggi hinggaakhir penyimpanan.

Tabel 3. Potensi Tumbuh Maksimum (\%)

\begin{tabular}{ccccccccc}
\hline \multirow{2}{*}{ Perlakuan } & \multicolumn{7}{c}{ Simpan } & \multirow{2}{*}{ Rerata } \\
\cline { 2 - 8 } & \multicolumn{1}{c}{ S0 } & S2 & S4 & S6 & S8 & S10 & S12 & 65,52 b \\
KM & $73.33 \mathrm{abc}$ & $74.67 \mathrm{ab}$ & $68.00 \mathrm{bcd}$ & $61.33 \mathrm{~cd}$ & $60.00 \mathrm{~d}$ & $57.33 \mathrm{~d}$ & $64.00 \mathrm{bcd}$ & $70,10 \mathrm{a}$ \\
\hline KL & $73.33 \mathrm{abc}$ & $68.00 \mathrm{bcd}$ & $74.67 \mathrm{ab}$ & $61.33 \mathrm{~cd}$ & $64.00 \mathrm{bcd}$ & $66.67 \mathrm{bcd}$ & $82.67 \mathrm{a}$ & - \\
\hline Rerata & $73,33 \mathrm{a}$ & $71,33 \mathrm{Ab}$ & $71,33 \mathrm{ab}$ & $61,33 \mathrm{c}$ & $62,00 \mathrm{bc}$ & $62,00 \mathrm{bc}$ & $73,33 \mathrm{a}$ & - \\
\hline \multicolumn{2}{l}{ Keterangan : Angka pada baris dan kolom yang diikuti dengan huruf yang sama tidak berbeda nyata menurut uji DMRT @ 5\%, KM : kamar, }
\end{tabular}

$\mathrm{KL}$ : kulkas, $\mathrm{S}$ : simpan, $(-)=$ Tidak terjadi interaksi antar faktor.

\subsection{Daya Berkecambah}

Daya berkecambah adalah potensi kemampuan benih berkecambah setelah penanganan yang optimal sehingga dapat mencerminkan hasil kecambah yang diharapkan pada saat persemaian.

Data Tabel 4. menunjukkan bahwa, perlakuan suhu kulkas dengan periode simpan S12, berpengaruh nyata dengan perlakuan lainnya tetapi tidak berbeda nyata dengan periode simpan S6. Daya berkecambah tertinggi terdapat pada benih yang disimpan pada suhu kulkas selama penyimpanan 12 minggu dan terendah padaperiode simpan S0. Untuk masing-masing suhu yakni suhu kulkas dan suhu kamar setiap persemaian selama penyimpanan jumlah daya berkecambah benih bersifat fluktuatif.
Sejak zaman prasejarah manusia telah mengetahui bahwa daya kecambah benih semakin menurun sejalan dengan bertambahnya umur benih (James, 1967). Untuk memperbaikinya maka harus memperhatikan cara penyimpanan suhu dan kelembapan. Meningkatnya daya kecambah benih yang disimpan berkaitan dengan menurunnya kadar air selama masa simpan. Kadar air benih yang disimpan pada suhu kulkas selama penyimpanan menyebabkan proses metabolisme benih berjalan lambat. Hal ini mengakibatkan daya kecambah semakin meningkat karena tersedianya cadangan makanan yang cukup sebagai substrat untuk mendukung proses perkecambahan. Bertambahnya substrat untuk respirasi menyebabkan energi yang dihasilkan untuk proses perkecambahan menjadi meningkat (Tatipata, et al. 2004). 
Tabel 4. Daya Berkecambah(\%)

\begin{tabular}{|c|c|c|c|c|c|c|c|c|}
\hline \multirow{2}{*}{ Perlakuan } & \multicolumn{7}{|c|}{ Simpan } & \multirow{2}{*}{ Rerata } \\
\hline & S0 & S2 & S4 & S6 & S8 & $\mathrm{S} 10$ & $\mathrm{~S} 12$ & \\
\hline KM & $50.67 \mathrm{de}$ & $74.67 \mathrm{ab}$ & $65.33 \mathrm{bcd}$ & 62.67 bcde & $65.33 \mathrm{bcd}$ & 60.00 bcde & $48.00 \mathrm{e}$ & $60,95 \mathrm{~b}$ \\
\hline KL & $50.67 \mathrm{e}$ & 64.00 bcde & $65.33 \mathrm{bcd}$ & $74.67 \mathrm{ab}$ & $56.00 \mathrm{de}$ & $70.67 \mathrm{abcd}$ & $81.33 \mathrm{a}$ & $66,10 \mathrm{a}$ \\
\hline Rerata & $50,67 \mathrm{e}$ & $69,33 \mathrm{a}$ & $65,33 \mathrm{c}$ & $68,67 \mathrm{ab}$ & $60,67 \mathrm{de}$ & $65,33 \mathrm{c}$ & $64,67 \mathrm{~cd}$ & - \\
\hline
\end{tabular}

Keterangan : Angka pada baris dan kolom yang diikuti dengan huruf yang sama tidak berbeda nyata menurut uji DMRT @ 5\%, KM : kamar, $\mathrm{KL}$ : kulkas, $\mathrm{S}:$ simpan, $(-)=$ Tidak terjadi interaksi antar faktor.

\subsection{Indeks Vigor}

Secara umum vigor diartikan sebagai kemampuan benih untuk tumbuh normal pada keadaan lingkungan yang sub optimal. Benih dengan vigor tinggi akan tumbuh lebih cepat karena benih tersebut berkecambah dalam waktu yang relatif singkat (Sadjad, et. al, 1999). Vigor benih yang tinggi dicirikan antara lain tahan disimpan lama, tahan terhadap serangan hama penyakit, cepat dan merata tumbuhnya serta mampu menghasilkan tanaman dewasa yang normal dan berproduksi baik dalam keadaan lingkungan tumbuh yang sub optimal.

Penurunan viabilitas dan vigor awal terkadang dipengaruhi oleh kondisi benih, dimana sebelum digunakan benih baru disimpan kurang lebih 2 bulan pada suhu kamar. Rendahnya vigor pada benih juga disebabkan oleh beberapa ha antara lain faktor genetis, fisiologis, morfologis, sitologis, mekanis dan mikrobia (Sutopo, 1998).

Data Tabel 5. menunjukkan bahwa perlakuan suhu kulkas dengan periode simpan S12 berbeda nyata dengan perlakuan laiinya tetapi tidak berbeda nyata dengan periode simpan S6. Penyimpanan di suhu kamar menyebabkan udara lingkungan dapat berhubungan langsung dengan ruang penyimpanan. Menurut hasil penelitian Kartono (2004), walaupun kadar air beih kedelai awal penyimpanan rendah, penyimpanan pada ruang terbuka menyebabkan kerusakan benih yang tinggi, menurunkan daya kecambah, dan daya simpan benih yang singkat. Sadjad et. al, (1999) menyatakan bahwa kemampuan berkecambah suatu benih berhubungan dengan banyaknya cadangan makanan yang dikandungnya.

Penyimpanan benih di daerah tropis yang memiliki suhu dan kelembaban tinggi sepanjang tahun dapat memperpendek masa simpan benih, karena kondisi ini akan memacu laju respirasi dan laju deteriorasi benih, sehingga persentase viabilitas benih akan cepat menurun. Menurut Isbagio (1979), kadar air benih tetap rendah dalam batas maksimal selama periode penyimpanan, maka benih akan dapat mempertahankan mutu dan kualitasnya, sehingga viabilitas dan vigor benih tetap baik dengan demikian jumlah kecambah normal semakin tinggi.

Indeks vigor cenderung meningkat pada benih yang disimpan pada suhu kulkas, selama periode simpan 12 minggu dan indeks vigor cenderung menurun pada benih yang disimpan pada suhu kamar, selama periode simpan 0 minggu. Jumlah kecambah normal pada setiap persemaian selama periode simpan dan kondisi suhu simpan bersifat fluktuatif. Moore, (1955) dalam Justice dan Bass (2002), menyimpulkan bahwa suatu benih mencapai puncak vigor pada saat benih masak, dan setelah itu vigor akan berkurang karena benih mengalami proses penuaan. Salah satu penyebab berkurangnya vigor benih setelah masak fisiologis dikarenakan adanya deraan cuaca dilapang akibat keterlambatan panen.

Benih yang telah disimpan akan mengalami deteriorasi yang ditunjukkan dengan penurunan vigor benih. Menurunnya vigor benih secara fisiologis ditandai dengan penurunan daya berkecambah dan peningkatan jumlah kecambah abnormal (Copeland dan Donald, 2001). Penyimpanan benih menghasilkan kecepatan berkecambah dengan nilai rata-rata semakin menurun dengan semakin lama periode penyimpanan. Penurunan nilai rata-rata kecepatan berkecambah menunjukkan bahwa benih mengalami penurunan daya kecambah selama proses penyimpanan dengan diikuti peningkatan persentase kadar air. Hal ini merupakan gejala biologis yang dialami oleh benih selama penyimpanan. Proses biologis yang dialami oleh benih selama penyimpanan salah satunyaadalah proses metabolisme, terutama proses respirasi yang terkait dengan proses kemunduran mutu benih. Kemunduran mutu benih selama penyimpanan dapat terjadi apabila cadangan makanan untuk pertumbuhan embrio berkurang atau habis akibat proses metabolisme respirasi (Roberts, 1972).

Tabel 5. Indeks Vigor (\%)

\begin{tabular}{ccccccccc}
\hline \multirow{2}{*}{ Perlakuan } & \multicolumn{7}{c}{ Simpan } & \multirow{2}{*}{ Rerata } \\
\cline { 2 - 8 } & \multicolumn{1}{c}{ S0 } & S2 & S4 & S6 & S8 & S10 & S12 & $42,29 \mathrm{~b}$ \\
KM & $28.00 \mathrm{e}$ & $57.33 \mathrm{~b}$ & $53.33 \mathrm{abc}$ & $49.33 \mathrm{abc}$ & $40.00 \mathrm{bcde}$ & $34.67 \mathrm{ce}$ & $33.33 \mathrm{de}$ & \\
KL & $28.00 \mathrm{~d}$ & $36.67 \mathrm{~cd}$ & $50.67 \mathrm{abc}$ & $60.00 \mathrm{a}$ & $36.00 \mathrm{~cd}$ & $48.00 \mathrm{abc}$ & $66.67 \mathrm{a}$ & $46,29 \mathrm{a}$ \\
\hline Rerata & $28 \mathrm{f}$ & $46,00 \mathrm{~d}$ & $52,00 \mathrm{~b}$ & $54,67 \mathrm{a}$ & $38,00 \mathrm{e}$ & $41,33 \mathrm{de}$ & $50,00 \mathrm{bc}$ & - \\
\hline
\end{tabular}

Keterangan : Angka pada baris dan kolom yang diikuti dengan huruf yang sama tidak berbeda nyata menurut uji DMRT @ 5\%, KM : kamar, $\mathrm{KL}$ : kulkas, $\mathrm{S}$ : simpan, $(-)=$ Tidak terjadi interaksi antar faktor.

\subsection{Keserempakan Tumbuh}

Data Tabel 6. menunjukkan bahwa keserampakan tumbuh cenderung meningkat pada benih yang disimpan pada suhu kulkas dan cenderung menurun pada benih yang disimpan pada suhu kamar. Keserampakan tumbuh tertinggi terdapat pada benih yang disimpan pada suhu kulkas selama periode simpan minggu ke-4, dan terendah pada benih yang disimpan pada suhu kamar selama periode simpan 0 minggu. Keserampakan tumbuh untuk setiap persemaian selama periode simpan jumlahnya bersifat fluktuatif. Naik turunnya jumlah kecambah normal setiap persemaian selama periode penyimpanan disebabkan faktor biologis dari benih tersebut, terutama pada fisik benih yakni terdapat penyakit pada benih, terdapat luka benih sehingga menyebabkan benih tidak dapat tumbuh yang berarti benih mati atau tidak tumbuh sama sekali. Proses biologis yang dialami oleh benih selama penyimpanan salah satunyaadalah proses metabolisme, terutama proses respirasi.

Perlakuan suhu kulkas dengan periode simpan S4, S6, S8, S10 dan S12 memberikan pengaruh berbeda nyata dengan perlakuan lainnya dan penyimpanan benih pada suhu kulkas selama periode simpan 4 minggu meningkatkan kecambah normal tertinggi. Hal ini disebabkan benih yang disimpan pada suhu kulkas dapat meningkatkan jumlah kecambah norma karena suhu kulkas dapat menghambat proses respirasi dengan demikian dapat mempertahankan daya hidup benih.

Tabel 6. Keserempakan Tumbuh (\%)

\begin{tabular}{|c|c|c|c|c|c|c|c|c|}
\hline \multirow{2}{*}{ Perlakuan } & \multicolumn{7}{|c|}{ Simpan } & \multirow{2}{*}{ Rerata } \\
\hline & S0 & $\mathrm{S} 2$ & S4 & S6 & S8 & $\mathrm{S} 10$ & $\mathrm{~S} 12$ & \\
\hline KM & $42.67 \mathrm{~b}$ & $64.00 \mathrm{a}$ & $62.67 \mathrm{a}$ & $60.00 \mathrm{a}$ & $58.67 \mathrm{a}$ & $44.00 \mathrm{~b}$ & $44.00 \mathrm{~b}$ & $53,71 \mathrm{~b}$ \\
\hline KL & $42.67 \mathrm{~b}$ & $45.33 \mathrm{~b}$ & $68.00 \mathrm{a}$ & $65.33 \mathrm{a}$ & $60.67 \mathrm{a}$ & $65.33 \mathrm{a}$ & $65.33 \mathrm{a}$ & $58,95 \mathrm{a}$ \\
\hline Rerata & $42,67 \mathrm{e}$ & $54,67 \mathrm{~d}$ & $65,33 \mathrm{a}$ & $62,67 \mathrm{~b}$ & $59,67 \mathrm{bc}$ & $54,67 \mathrm{~d}$ & $54,67 \mathrm{~d}$ & - \\
\hline
\end{tabular}

Keterangan : Angka pada baris dan kolom yang diikuti dengan huruf yang sama tidak berbeda nyata menurut uji DMRT @ 5\%, KM : kamar, $\mathrm{KL}$ : kulkas, $\mathrm{S}$ : simpan, $(-)=$ Tidak terjadi interaksi antar faktor.

\subsection{Berat Kering Kecambah Normal}

Berat kering kecambah normal merupakan salah satu indikator viabilitas (Sutopo, 2004), tingginya nilai BKKN menunjukkan tingginya viabilitas benih (Justice dan Bass, 2002). Dalam penelitian setiap persemaian selamapenyimpanan, seluruh kecambah normal dari semua parameter dioven selama 72 jam lalu ditimbang untuk memperoleh nilai barat kering kecambah normal $(\mathrm{BKKN})$.

Data Tabel 7. menunjukkan bahwaperlakuan suhu kulkas dengan periode simpan S12 berbeda nyata dari perlakuan lainnya. Berat kering kecambah normal cenderung meningkat pada benih yang disimpan pada suhu kulkas dan cenderung menurun pada benih yang disimpan pada suhu kamar. Prawiranata et al., (1992) menjelaskan benih yang memiliki viabilitas tinggi mampu menghasilkan berat kering kecambah yang tinggi pada kondisi optimum dan suboptimum pada benih yang disimpan padasuhu kulkas.Berat kering kecambah normal tertinggi pada suhu kulkas selama penyimpanan minggu ke-12, dan terendah pada suhu kamar selama penyimpanan 0 minggu. 
Tabel 7. Berat Kering Kecambah Normal (Gram)

\begin{tabular}{|c|c|c|c|c|c|c|c|c|}
\hline \multirow{2}{*}{ Perlakuan } & \multicolumn{7}{|c|}{ Simpan } & \multirow{2}{*}{ Rerata } \\
\hline & S0 & $\mathrm{S} 2$ & S4 & S6 & S8 & S10 & S12 & \\
\hline KM & $0.090 \mathrm{~g}$ & $0.150 \mathrm{ab}$ & $0.143 \mathrm{bcd}$ & $0.140 \mathrm{bcd}$ & 0.126 ef & $0.116 \mathrm{f}$ & $0.093 \mathrm{~g}$ & $0,12 \mathrm{~b}$ \\
\hline KL & $0.090 \mathrm{~g}$ & $0.133 \mathrm{~g}$ & $0.143 \mathrm{bcd}$ & $0.150 \mathrm{abc}$ & 0.136 cde & $0.146 \mathrm{abcd}$ & $0.160 \mathrm{a}$ & $0,14 \mathrm{a}$ \\
\hline Rerata & $0,09 \mathrm{c}$ & $0,14 \mathrm{~b}$ & $0,14 \mathrm{~b}$ & $0,15 \mathrm{a}$ & $0,13 b c$ & $0,13 \mathrm{bc}$ & $0,13 \mathrm{bc}$ & - \\
\hline
\end{tabular}

Keterangan : Angka pada baris dan kolom yang diikuti dengan huruf yang sama tidak berbeda nyata menurut uji DMRT @ 5\%, KM : kamar, $\mathrm{KL}$ : kulkas, $\mathrm{S}:$ simpan, $(-)=$ Tidak terjadi interaksi antar faktor.

\section{Simpulan}

Benih yang disimpan pada perlakuan suhu kamar dapat meningkatkan kadar air benih tetapi dapat menurunkan viabilitas serta vigor benih, sedangkan benih yang disimpan pada perlakuan suhu kulkas dapat menurunkan kadar air benih tetapi dapat meningkatkan viabilitas serta vigor benih. Dari semua parameter penelitian ini, perlakuan yang terbaik adalah pada perlakuan benih yang simpan pada suhu kulkas, terutama pada parameter kecepatan tumbuh $\left(\mathrm{K}_{\mathrm{c}} \mathrm{t}\right)$, potensi tumbuh maksimum, daya kecambah, indeks vigor, keserampakan tumbuh, berat kering kecambah normal. Padasuhu kulkas, respirasi berjalan lambat sehingga, viabilitas benih dapat dipertahankan lebih lama, dan dapat menigkatkan vigor benih, sedangkan padasuhu kamar respirasi berjalan cepat sehingga menimbulkan resiko terserang cendawan, dengan demikian dapat menurunkan viabilitas serta vigor benih tomat lokal.

\section{Pustaka}

Copeland, L. O. dan M. B. McDonald. 2001. Seed Science and Technology. Kluwer Academic Publishers. London. 425 hal.

Delouche, J.C. 1971. Determinants of Seed Quality. Seed Technology Laboratory Mississippi State University, Mississippi State, Mississippi.

Direktorat Jenderal Hortikultura. 2011. Produksi Tomat. [Diunduh 2015 Agustus 10]. Tersedia pada http://www.deptan.go.id

Gomez, K. A. and Gomez A. A. 1995. Prosedur Statistik Untuk Penelitian Pertanian. Edisi ke 2. UI Press: Jakarta

Harrington, J. C. 1973. Problems of seed storage, p. 251-263. In: Heydecker $(E d)$.Seed Ecologi. Academy Prees. London.

Isbagio, P. 1979. Evaluasi dan Interpretasi dalam Pengujian Benih Мenuju Standarisasi Benih. Lembaga Penyuluhan Pertanian, Bogor.

James, Edwin. 1967. Mechanical control of Seed Stocks. Adv. In Agron. 19:87106.

Justice, O.L. dan L.N. Bass. 1994. "Prinsip Praktek Penyimpanan Benih". Diterjemahkan oleh Rennie Roesli. Raja Grafindo Persada. Jakarta.

Justice, O. L. dan L. N. Bass. 2002. Prinsip dan Praktek Penyimpanan Benih. Raja Grafindo Persada. Jakarta.

Kartono. 2004. Tehnik Penyimpanan Benih Kedelai Varietas Wilis Pada Kadar Air dan Suhu Penyimpanan Yang Berbeda. Buletin Tehnik Pertanian Volume 9 Nomor 2 Tahun 2004.

Prawiranata, W., S. Harran. dan P. Tjndronegoro. 1992. Dasar-dasar Fisiologi Tumbuhan. Fakultas Matemetika dan Ilmu Alam. IPB Bogor. 247 hal

Raka, G.N., M. Astiningsih, D.N Nyana,dan K. Siadi. 2012. Pengaruh Dry Heat Treatment Terhadap Daya Simpan Benih Cabai Rawit (Capsicum frutescens L.). Journal Agric. Sci. and Biotechnol 1 (1): 1-10.

Roberts, E.H. 1972. Viability of Seed. 488 hlm., illus. London.

Sadjad, S. 1980. Teknologi Benih dalam Masalah Vigor. Dasar-dasar Teknologi Benih. Departemen Agronomi Faperta, IPB. Bogor. 125 hal.

Sadjad, S. E. Muniarti dan S. Ilyas. 1999. Parameter Pengujian Vigor Benih dari Komparatif ke Simulatif. Grasindo. Jakarta. 184 hal.

Sutopo, L. 1998. "Teknologi Benih". Raja Grafindo Persada. Jakarta.

Sutopo, L. 2004. Teknologi Benih. Edisi Revisi. Raja Grfindo Persada. Jakarta.

Tatipata, A., P. Yudono., A. Purwantoro., dan W. Mangoendidjojo. 2004. Kajian Aspek Fisiologi Dan Biokimia Deteriorasi Benih Kedelai Dalam Penyimpanan. Ilmu Pertanian 11 (2): 76-87

Viera, R.D., D.M. Tekrony, D.B. Egli, M. Rucker. 2001. Electrical conductivity of soybean seeds after storage in several environments. Seed. Sci. Technol. 29:599-608 